Nature 333, 754 - 757 (23 June 1988); doi:10.1038/333754a0

\title{
Interannual variability in climate and fisheries in Tasmania
}

\author{
G. P. Harris*, P. Davies $\dagger$, M. Nunez $\dagger \&$ G. Meyers§
}

*Division of Fisheries, CSIRO Marine Labor atories, GPO Box 1538,Hobart, Tasmania 7001, Australia

$\dagger$ Inland Fisheries Commission, Hobart, Tasmania, Australia

\$Department of Geography, The University of Tasmania, Tasmania,Australia

§Division of Oceanography, CSIRO Marine Laboratories, Hobart, Tasmani a, Australia

Whereas the interannual variability of the climate and fisheries of the Northern Hemisphere has been extensively documented1, very little is known about the interannual variability in the fisheries of the Southern Pacific Region. Recent work in the Norther $n$ Hemisphere has demonstrated the close relations between interan -nual variability in climate, the timing of events in the water column, the structure of food chains and recruitment to both marine and freshwater fisheries2,3. Forty years (1945-85) of observations at a coastal station (Maria Island, $42^{\circ} 36 \mathrm{~S}, 148^{\circ} 16^{\prime} \mathrm{E}$ ) in Tasmania showed strong interannual variability in sea-surface temperatures. Maria Island is close to the region of convergence of the surface currents, on the equatorial side of the Subtrop ical Convergence (STC) water mass boundary4. The spring bloom was often extended by as much as three months in some years. Previous work4 has not offered any explanation for the observed interannual variability and does not show any links with commercial fisheries. Here we explain the reason for the interannual climatic and oceanic vari -ability in Tasmania and show the links between climate and the fisheries.

References 1. Cushing, D. H. Climate and Fisheries (Academic Press, London, 1982).

2. George, D. G. \& Harris, G. P. Nature 316, 536-539 (1985). | Article |

3. Harris, G. P. Phytoplankton ecology (Chapman and Hall, London, 1986).

4. Harris, G. P., Nilsson, C., Clementson, L. A. \& Thomas, D. P. Aust. J. mar. Freshwat. Res. 38, 569-590 (1987). | ChemPort |

5. Williams, M. BMRC Res. Rep. 6. (Bureau Met. Res. Centre, Melbourne, 1987).

6. van Loon, H. \& Shea, D. J. Mon. Weath. Rev. 113, 2063 -2074 (1985). | Article |

7. Sverdrup, H. U. J. Cons. perm. int. Explos. Mer. 18, 287 -295 (1953).

8. Wyrtki, K. CSIRO Div. Fish. Oceanogr. Tech. paper 8, Hobart (1960).

9. Edwards, R. J. CSIRO Div. Fish. Oceanogr. Rep. 88, Cronulla (1979).

10. Smith, P. J., McKoy, J. L. \& Machin, P. J. N.Z. J. mar. Freshwat. Res. 14, 55 -63

(1980). 
11. Booth, J. D. Can. J. Fish. Aq. Sci. 43, 2212-2220 (1986).

12. Phillips, B. F. \& McWilliam, P. S. Can. J. Fish. aq. Sci. 43, 2153 -2163 (1986).

13. Lutjeharms, J. R. E. \& Heydorn, A. E. F. Deep Sea Res. 28, 631 - (81).

14. Pearce, A. F. \& Phillips, B. F. J. Cons. perm. int. Explor. Mer. 45(1) (in the press).

15. Harrison, A. J. Aust. Fish. News lett. 9-13, June 1965.

16. Rochford, D. J. CSIRO Div. Fish. Oceanogr. Rep. 114, Hobart, (1981).

17. Rounsevell, D. \& Eberhard, I. Aust. J. Wildl. Res. 7, 403 -415 (1980).

18. Paul, L. J. Proc. Pelagic. Fish. Conf. N.Z. MAFF Fish. Res. Div. Occ. Publ. 15, 70-74 (1978).

19. Davies, P. E. \& Sioane, R. D. J. Fish. Biol. 31, 353 -373 (1987).

20. Box, G. E. P. \& Jenkins, G. M. Time Series Analysis (Holden -Day, San Francisco, 1976).

21. Harris, G. P. \& Trimbee, A. M. J. Plank. Res. 8, 1011 -1025 (1986). 